\section{Letters, Notes, and Answers}

All communications in regard to editorial business should be addressed to The EDITOR, British Medical Journal, B.M.A. House, Tavistock Square, W.C.1.

ORIGINAL ARTICLES and LETTERS forwarded for publication are understood to be offered to the British Medical Journal alone, unless the contrary be stated. Correspondents who wish notice to be taken of their communications should authenticate them with their names, not necessarily for publication.

Authors desiring REPRINTS of their articles published in the British Medical Journal must communicate with the Secretary, B.M.A. House, Tavistock Square, W.C.1, on receipt of proofs. Authors over-seas should indicate on MSS. if reprints are Authors over-seas should indicate on
required, as proofs are not sent abroad.

ADVERTISEMENTS.-All communications should be addressed to the Advertisement Manager (office hours, 9 a.m. to 5 p.m.). Orders for copies of the Journal and communications with reference to subscriptions should be addressed to the Secretary, B.M.A. House.

The Telephone Number of the British Medical Association and the British Medical Journal is EUSTON 2111.

The Telegraphic AdDresses are EDITOR OF THE BRITISH MEDICAL JOURNAL. Aitiology Westcent, London.

SECRETARY, Medisecra Westcent, London.

The address of the B.M.A. Scottish Office is 7, Drumsheugh Gardens, Edinburgh (telegrams: Associate, Edinburgh; telephone 24361 Edinburgh), and of the Office of the Cumann Doctúirí na h-Éireann (I.M.A. and B.M.A.), 95, Merrion Square, W., Dublin (telephone 62550 Dublin).

\section{QUERIES AND ANSWERS}

\section{Laryngeal Diphtheria in a Woman of 72}

Dr. Findlater Brown (Kingston, Jamaica) writes: Allow me space to direct the attention of your readers to a case of laryngeal diphtheria (verified bacteriologically) in a female patient 72 years of age. She was severely ill, and was made worse by marked cerebral symptoms. Recovery was uneventful, the patient leaving hospital on the twentieth day of her stay and on the twentysecond day of her illness. What interests me at this moment is the age of the patient. Can any information be obtained from others possessed of experience in parallel cases? The maximum age of individuals in whom this disease occurs in Jamaica is 55 years.

\section{Income Tax}

\section{Allowance for Wife's Earnings}

Inquiries have reached us as to the conditions under which some relief is obtainable in respect of payments made to a wife for assistance in the practice.

** Payments made to a wife by her husband for assistancefor example, in keeping the books, attending to or supervising the cleaning of the surgery, waiting room, etc.-are deductible in calculating the husband's profits, but of course are assessable on the wife as her income. The latter fact, however, does not leave things as they would have been if the payments had not been made, because under Section 18 of the Finance Act, 1920 an additional allowance is due in respect of a wife's earned income. For 1940-1 this allowance will be five-sixths of that earned income or $£ 45$, whichever is the less. Thus if the "wages" paid to the wife have been $£ 52$ for the year, the earned income allowance will be $1 / 6$ of $£ 52=£ 9$, and the special allowance will be $£ 43$, the combined reliefs covering the $£ 52$ and leaving no net assessment on which tax will be payable. There is thus a clear gain as compared with the tax payable if no "wages" had been paid for the wife's work in the practice. In passing it may be pointed out that whereas for 1939-40 £56 would similarly have escaped net liability, the reduction in the earned income relief to one-sixth for 1940-1 will produce for that year an assessment on the wife's earnings of $£ 56-(£ 9+$ $£ 45=) £ 54$-that is, $£ 2$ at, presumably, $7 \mathrm{~s}$. $6 \mathrm{~d}$.- that is, $15 \mathrm{~s}$. It may be a little irritating to receive a supplemental demand for this small amount of tax, but it will at least be a guarantee that full advantage has been taken of the special allowance. The revenue authorities usually require some evidence that the $£ 50$ was paid as between employer and employee and not as part of the domestic financial arrangements between husband and wife - that is, that a sum was agreed as payable for services to the practice, that some duties were in fact performed, and that the agreed payments were made and duly recorded in the books of the practice. Retrospective effect to such arrangements will not be given.

\section{LETTERS, NOTES, ETC. \\ "Mental Health"}

The first number, dated January, 1940, of a new periodical, Mental Health, has been published jointly by the National Council for Mental Hygiene (76, Chandos House, Palmer Street, S.W.1), the Central Association for Mental Welfare (24, Buckingham Palace Road, S.W.1), and the Child Guidance Council (emergency address, 23, Queen Square, Bath). It takes the place of the previous quarterly Mental Hygiene and of Mental Welfare, and the editorial board consists of Dr. Doris M. Odlum, Miss Evelyn Fox, and Dr. R. G. Gordon. The price of single copies is 10d. annual subscription, 3s. 6d., post free. It has long been the desire of the three organizations to achieve closer co-operation ; and the need for economy and for avoiding overlap and waste of effort, which has become imperative owing to the war, gave an opportunity for taking the first step towards this goal. The joint journal, with wider scope, should represent the whole field of mental health in true proportion, and the linking up of the Child Guidance Council will extend the field in a way which is most important at all times, and especially during a war. The three opening papers of the first number are by Dr. Emanuel Miller, on "The Bedwetting Problem"; by Miss Edna M. Henshaw, on "Some Psychological Difficulties of Evacuation"; and by Mr. John C. Raven, on "Matrix Tests for assessing Mental Ability, designed in accordance with Psychological Principles." These articles are followed by current news and notes, and book reviews.

\section{Treatment of Influenza}

Dr. D. Ockman (Kearsley, Lancs) writes: I have read with much interest the treatment of influenza described by Dr. W. N. Leak (February 17, p. 286). Perhaps your readers may be interested to know an alternative treatment based on an alternative conception of disease. I consider influenza to be a saturation of the blood by the influenza toxin, a condition well within the powers of the vis medicatrix naturae. (1) Seidlitz powders for detoxication, relief of headache, etc. (2) Ample fluids, such as hot black-currant tea, etc., for diaphoresis, diuresis, expectoration. (3) High vitamin diet of egg-yolk, orange juice, milk, fruit. (4) Mist. camph. co., to promote expectoration. I have thus " cured" scores of cases of influenza without the aid of aspirin, phenacetin, barbitone, hyoscine, sulphapyridine, chloroform, morphine, or bromides. All my patients have returned to work without carrying a miscellaneous variety of chemicals in their blood.

\section{Herniotomy at the Age of 93}

Professor G. Grey Turner, F.R.C.S., writes: If Drs, J. A. Ross and A. Fraser will look among the "Letters, Notes, etc." of the British Medical Journal for February 27, 1932 (p. 410), they will find a brief communication from me, in response to an earlier one by my friend Dickie of Middlesbrough, on operations in old age. There is related the case of a man of 93 on whom I was persuaded to operate for a double inguinal hernia. Strangulation demands operation whatever life's span, but I question the wisdom of a radical cure except under exceptional circumstances.

Mr. C. C. Holman, F.R.C.S. (Northampton), writes: Drs. Ross and Fraser (February 17, p. 256) wish to hear of a similar case. On February 19, 1928, I operated on a man of 90 for radical cure of a large direct hernia; it was not strangulated, but gave him much pain. I used a local anaesthetic; the only drawback to this was the difficulty of maintaining communication with a patient who, although vigorous, was stone deaf. Recovery was uneventful, and he carried on an active existence until his death some six months later.

\section{Corrigendum}

Dr. Gerald St.ot (London, W.1) writes: In your issue of February 17 (p. 272) I am reported as having said that picrotoxin is the best agent for dealing with barbiturate pneumonia. This is an inaccurate report. I have no experience of picrotoxin in barbiturate pneumonia. What I said was that for resuscitation and stimulation of the respiratory centre when caused by an overdose of barbiturate, picrotoxin given at fifteen-minute intervals intravenously seemed to me to be the most valuable agent, and such a solution might find a place on the anaesthetic table. This drug is apparently far more widely known in America than here. From private conversations with several anaesthetists, they seem to confirm this view. I hope to publish a short paper on this soon.

Schools, 1940, published by Truman and Knightley, Ltd., scholastic agents, of 61, Conduit Street, W.1, includes an evacuation supplement giving the addresses of evacuated schools. The price is $3 \mathrm{~s}$; ; postage 6d. (abroad 1s.). 